Ђорђе М. Деспић

Филозофски факултет

Универзитет у Новом Саду
УДК: 821.163.41-4.09 Pavlović M.

DOI: 10.19090/gff.2021.1.191-203

Оригинални научни рад

\title{
О ПРОБЛЕМСКИМ И ДИСКУРСНИМ АСПЕКТИМА ДНЕВНИКА ПЕНЕ МИОДРАГА ПАВЛОВИЋА
}

Текст тежи да истакне проблемске и дискурсне специфичности Дневника пене Миодрага Павловића. У контексту рецепције Павловићевог есејистичког опуса ова есејистичка књига није привукла пуно пажње, иако садржи важна и луцидна промишљања битних књижевних феномена који одликују добар део његовог укупног стваралаштва, попут песничке имагинације, мита, модерности, еротског, антислике. Такође, рад ће настојати да аналитички укаже на Дневник пене као на дискурсно слојевиту књигу, коју карактеришу жанровска хетерогеност и фрагментарност у поступку.

Кључне речи: есеј, поезија, дискурс, имагинација, мит, еротско, фрагментарност

\section{ДНЕВНИК ПЕНЕ}

Павловићева књига Дневник пене (Павловић, 1972) својом посебношћу донекле се издваја из његовог укупног есејистичког опуса. Док су готово све остале одавале мање или више проблемску усредсређеност и жанровску хомогеност, расправљајући о начелној књижевној проблематици (Рокови поезије, Поетика модерног), или о антрополошким темама (Поетика жртвеног обреда, Говор о Ничем, Храм и преображење), бавећи се српском или светском књижевношћу (Осам песника, Поезија и култура, Ништитељи и свадбари, Есеји о српским песнииима, Читање замишљеног), фокусирајући се на тачно одређене књижевне просторе (Обредно и говорно дело, Огледи о народној и старој српској поезији), ова своју посебност намеће понајпре својом хетерогеношћу и у проблемској, и у дискурсној остварености. Можда се управо у хетерогености, фрагментарности и жанровској неухватљивости

\footnotetext{
*djordje.despic@ff.uns.ac.rs

** Рад је настао као део научног пројекта 178005, чији је руководилац проф. др Светлана Томин, а који финансира Министарство просвете, науке и технолошког развоја Републике Србије.
} 
ове књиге скрива разлог недовољно посвећене пажње коју јој је критика поклонила, премда је у скоро две трећине књиге ипак присутна линија која тематски и идејно повезује ове есеје. ${ }^{1}$

На проблемском нивоу уводни текстови „Модерност и песништво“, „Песничка имагинација као непосредно искуство“ и „Мит и поезија“, јасно тематизују феномен поезије и однос који она успоставља према миту и модерности. У том погледу, данас се посебно чини важним један од вероватно најцитиранијих Павловићевих термина - појам антислике. Под овим термином Павловић заправо подразумева сам концепт стварања и уопште природу модерног песништва. У Дневнику пене он не само да га јасно изражава, и не само да му служи као перспектива из које ће посматрати и промишљати неке друге феномене у овој књизи, већ је јасно да је овај термин заправо иманентна поетичка основа доброг дела његовог властитог песничког поступка ${ }^{2}$ :

Модерна уметност (је) она која ствара антислику свога друштва.

Антислика: оно што је супротно текућој митологији једног друштва, што оспорава прилагођену психологију свакодневице, навикнуте облике осећања, устаљене реакције па и устаљене идеале...

Антислика критикује психолошку, политичку, вредносну фасаду једног друштва (Павловић, 1972: 10).

Павловић наглашава да антислика није полемичка нити политичка, и посматрајући његов песнички опус налазимо да је ту идеју конзистентно заступао. Антислика је најпре уметничка перспектива, она је преиспитивалачка, реактуелизујућа, реинтерпретацијска, и не мири се са рутинским облицима и представама које настају на линији друштвенокултурне и митско-историјске инерције. Отуда је треба разумети као сигнал мисаоног и критичког, али и креативног субјекта: сигнал субјекта који је свестан света око себе, али који не жели да буде део пасивног прихватања задатих и окошталих релација, већ напротив - мислећи субјект који жели да поетски утиче на односе јер верује у виталистички принцип поезије и света.

\footnotetext{
${ }^{1}$ Преостали део Дневника пене представљају текстови писани раније а сада придодати при крају књиге, без чвршћег ослањања на претходећу структурну основу.

${ }^{2}$ На овај појам скретали смо пажњу у, настојећи да укажемо на везу експлицитних аутопоетичких ставова са поступком илуминативне цитатности за којом Павловић најрадије у својој поезији посеже (Деспић, 2008).
} 


\section{Песничка имагиначија као непосредно искуство}

Дискурсна разноврсност и игривост, као једна од основних одлика Дневника пене, лако се уочава у поглављу „Песничка имагинација као непосредно искуство“, где аутор свој есејистичко-теоријски дискурс преплиће са оним поетским. Ово свакако није особина само ове есејистичке књиге, на њу се наилази и другде, на шта је критика својевремено скретала пажњу, као што је то случај са Поетиком модерног и Ништитељима и свадбарима, поводом којих Славко Гордић износи прецизно запажање да Павловићева „критичка будност неретко нараста у светлост поетског“ (Гордић, 1981: 452). Разматрајући феномен песничке слике, Павловић овде на малом простору проблем песничке визуализације преводи у свет персонификовано оживљених релација, где не само да слика зависи од читаоца, већ она као да постаје свесни део у самом процесу свог конституисања. Тако се кроз поетскоесејистички дискурс изражава вид мистичне егзистенције саме песме:

Она тражи да дефинише односе нашег стварног света, и кроз то да се приближи његовој дубљој природи. Песма види односе у којима живимо као слику. Посматрајући нас, песма је или испод нас, у светлостима паклених ватри, или је изнад нас, као дух који лебди изнад неке метрополе, покушавајући да однесе смирење. Посматрајући како се у њој успостављају наши односи, сама песма може пасти у очајање. Може се осећати као неко жив сахрањен (Павловић, 1972: 15) .

Но, Павловић луцидно наслућује дубљу поетску истину проблема имагинације: „Имагинација није само опис моје људске ситуације, она је део те ситуације“ (Павловић, 1972: 17). У том смислу, он даље развија ту поставку мишљу да као што његова ситуација ствара песничку слику и слика, рекли бисмо - интерактивно, мења његову ситуацију. Стога његово промишљање имагинације подразумева својеврсну тростепеност у оквиру које се одвија рефлексија над феноменом настајања песничке слике, односно процесом и дејством имагинације. Прва имагинација је за њега почетни стадијум тог процеса, идеја или представа о позицији, о положају самог субјекта. Друга настаје када се идеја вербално реализује и „сједини“ са сликом, ${ }^{3}$ док трећим

\footnotetext{
${ }^{3}$ О том степену, о „слици-ситуацији“, Павловић ће касније говорити и у Поетици модерног, премда су ти есеји („Говор песничке слике“ и „Како настаје песма“) датирани 1966, односно 1967. годином, што значи да су писани пре објављивања Дневника пене, и да је то проблем који га је тих година интензивно привлачио.
} 
степеном имагинације Павловић именује оно што песми находи и у шта песник више нема увида, јер дејство песничке „слике-ситуације“ постаје део читалачког доживљаја. Тиме аутор песничку слику и имагинацију разматра од феноменолошког почетка и стадијума идеје, преко њеног вербалног оваплоћења и текстуалне реализације, до рецепцијског нивоа и конституисања слике у читалачком доживљају. Притом, тежњу и потребу да процес имагинације рашчлани и есејистички изрази, Павловић не артикулише искључиво кроз дискурс својствен рационалном промишљању, већ га прожима и нијансом поетски егзалтираног израза, сугеришући и тиме тему свог говора, будући да се у читаоцу подстиче не само појмовно-рационална већ и имагинацијска покретљивост.

Није никаква новост нагласити његово ниско вредновање поезије код које се имагинација заснива на „склапању лепих вербалних слика“, и која тиме постаје тек „домен гимнастике и забаве“ (Павловић, 1972: 18), и одавно је јасно да је рефлексивност у песништву она особина коју Павловић највише цени. На првом месту, она је иманентна његовој поезији, јавља се и као основни критеријум при састављању Антологије српског песништва, док у његовим есејима о књижевности представља незаобилазан ниво испитивања и оцењивања. Отуда је за њега „најдубља имагинација давање смисла“. Павловић се у ствари оглашава двоструко: и као теоретичар, и као песник. Он песничку слику-ситуацију види као приказ своје ситуације, не нужно уско схваћене, већ пре оне архетипске које се понављају и њему, и човеку уопште. У овим ставовима огледа се одлика елиотовске оформљене поетике, код које стваралачки императив лежи у препознавању садашњости у прошлости, и нужности да се током укупног песничког развоја негује та свест о прошлости. Јер иако се историја мења, архетипови човекове ситуације се понављају. Отуда је „моје место у једној ситуацији заменљиво за једно друго место у неком другом историјском оквиру са сличним вербално-ситуационим односима“ (Павловић, 1972: 19). Ово између осталог треба схватити као облик појашњења његовог карактеристичног посезања за поступком „песме са улогом“ (Кајзер, 1973: 228), које треба убедљивије да сугерише искуство појединца у тим архетипским ситуацијама. ${ }^{4}$

Имагинација је очито једна од великих Павловићевих есејистичких тема. Њој ће већ у Роковима поезије из 1958. године посветити озбиљну

\footnotetext{
${ }^{4}$ Најупечатљивији примери таквог поступка у Павловићевој поезији присутни су у збиркама Млеко искони, Велика скитија, Светли и тамни празници, рецимо.
} 
пажњу у оквиру текста „Дис или песничка имагинација“, док ће му у есејима о песницима увек бити важно у каквом се светлу имагинација одабраних стваралаца представља. Овде, међутим, она бива додатно, додуше имплицитно, наглашена и као битан аутопоетички елемент. Аутор, наиме, јасно истиче да је за њега, „смрт велико искушење имагинације. Смрт појединачна и смрт историјска, свеопшта, државна“ (Павловић, 1972: 25), чиме се овај феномен наглашава као чворишни, и можда главни проблем (песничке) уметности. То су у ствари оне ситуације које Павловић својом поезијом непрестано имагинативно промишља и реактуелизује: моменти преломних цивилизацијских, епохалних тачака, нестајање култура и настајање историјских промена, дато кроз апстраховану ситуацију и искуство индивидуе. То је свакако у функцији проблематизовања човекове повесне судбине, његовог друштвено-културног и духовног искуства, али то је уједно и уметничка афирмација негативне имагинащије: архетипска тежња ка спознаји смрти, коју аутор препознаје у стиховима поеме Робера Мартоа:

Тренутак негативне имагинације: (...) Тачном анализом акта насилне и жртвене смрти песник не жели само да се ослободи страха од телесног рашчињавања, декомпозиције, него хоће да своју имагинацију доведе у такву близину смрти саме, да би му она показала свој лик и оно што иза ње стоји (Павловић, 1972: 25).

\section{Мит и поезија}

Промишљајући имагинацију даље и у есеју „Мит и поезија“, Павловић нарочито истиче онај њен вид који рачуна са архетипским претпоставкама. Његово схватање мита доста дугује Фрајевим схватањима из Анатомије критике, које ће благовремено усвојити, па онда даље развити, продубити и конкретизовати у светлу својих интересовања. Овде му пажњу привлачи и сама имагинација утемељена на миту и митском мишљењу („Мит је граматика песничког мишљења, мит је граматика имагинације“) (Павловић, 1972: 29) ${ }^{5}$, али и песници ослоњени на мит, како они који га сакрализују (Овидије, класицисти 18. века, Милтон), тако и они који му удахњују нов смисао (Хелдерлин, већина романтичара). А потом и песници митопоезе - Блејк, Његош, Гете и, по Павловићу највећи у том контексту - Данте. Он тачно

\footnotetext{
${ }^{5}$ Упореди Фрајев став: „Библијска Апокалипса наша је граматика апокалиптичких пјесничких слика“ (Фрај, 1979: 162).
} 
наглашава могућност да сваки човеков тренутак, свака човекова ситуација може имати архетипску ознаку, да може изазвати одређене митолошке релације, реминисценције, асоцијације. Но, управо у том присуству мита у животу могуће су и злоупотребе, могућ је прелазак у манир, и стога се јавља потреба да се изврши демитизација свугде где се препознаје да мит у својој окошталој слици и оквиру губи енергију:

Отуд демитизација, разбијање идола, уклањање свега што нема битну стваралачку енергију. Склањање умртвљеног оквира, отискивање у оно непознато што борави иза навикнуте слике. Хоће најзад слику која се крије иза слике, мит иза мита, женско иза жене (Павловић, 1972: 32).

Ови ставови просто дозивају Павловићев стваралачки поступак реинтерпретације мита и повести који је у том моменту већ обележио његов дотадашњи поетски опус. Стога његови редови имају значај луцидног промишљања феномена имагинације и статуса митског у модерној уметности, али и снагу аутопоетичког оглашавања. ${ }^{6} \mathrm{C}$ друге стране, он одриче исправност ставу да модерна уметност своју окренутост миту заснива на класицистичким начелима обнове и неговања лепог из прошлости. Као аутентичан модерниста, Павловић истиче оно што и он сам у својим стиховима испољава, а то је да модерна лирика (и уметност уопште) не тежи да буде лепа и хармонична, и то је тенденција која, подсећа нас Хуго Фридрих, наглашено тече од Бодлера. Но, додатна специфичност његовог промишљања мита састоји се о томе што га проблематизује не само у односу према (модерној) књижевности, већ што разматра и његову улогу, или барем последице, које његово прихватање или одбацивање може уопште оставити по биће савременог човека. И то како у социолошком и економском, тако и у психолошком и политичко-идеолошком облику.

У овом фрагментарном сагледавању пуно је претпоставки, питања и одрицања, пуно је и имплицитне полемичности, а сам дискурс развија се на принципима изношења теза и антитеза, и кроз изградњу смисаоних обрта и ефектних закључака, који опет остају некако отворени у обећању парадокса:

\footnotetext{
${ }^{6}$ У том контексту не чуди питање које поставља, а које уједно открива његову поетичку позицију: „Историја је оно у чему се све људско догађа, у историји се догађа и неисторијско. Зашто поезија није од историје начинила своју привилеговану област?“ (Павловић, 1972: 34).
} 
Митолози и песници, каже Платон, не треба им веровати.

Бити против маште, у име чистог сазнања, уређеног друштва...

Мит је у животу оно што није уређено, што није сазнато.

Добро уређено друштво не би имало потребу за митом.

Против мита су они који тврде да је све уређено или да се све може уредити, да је све сазнато или да се све може сазнати.

Против мита су они који сами хоће да буду мит. За мит су они који неће да тај неко ко хоће да буде мит, заиста постане мит (Павловић, 1972: 39).

Павловићев захтев да се у митско не сме веровати потпуно кореспондира са његовом песничком природом. У том случају такав би простор постао окамењен, дефинитивно уобличен, а самим тим и уметнички неподстицајан. Миту треба приступати тек са слутњом истине, што је и видљиво у његовим (ре)актуализацијама митских простора: могућност увиђања, па и придавања нијанси новог и другачијег смисла који се онеобичено прелама кроз призму савременог субјекта.

Фрагментарност дискурса је више него очигледна на овим Павловићевим страницама. Текст бива формално „распарчан“ и графички раздвојен симболима, укидајући линеарност и континуум читања, док фрагменти покаткад садрже тек једну реченицу, као на пример у овом следу: „Све што остаје нерешено у нашем животу, у миту је; он одговара мишљењу под притиском ^ Митови нису 'фантастика', за коју неко добро рече да нам доноси само посувраћене клишее“ (Павловић, 1972: 40). У његовом „испрекиданом“ разматрању односа мита и поезије, па и самога мита, многа запажања плене дубином понирања и откривања нових физиономија посматраних феномена. Ови Павловићеви увиди доживљавају се као прави просеви луцидности, и поимају се понекад као аутентични поетскорефлексивни изрази: „Песничка реч хоће да прође између пламена и пепела“; „Мит је једна динамична граматика, која спаја језичку граматику са граматиком људских збивања. Сакрално је и у језичком и у телесном“, а понекад као емпиријски непорециве максиме: „Мит је вишезначан, прилагодљив, еластичнији од институција које га понекад носе и заступају“; „Митови се револуционишу, њихова вишезначност је историјски реална“.

Павловићева мисао плени својим дубоким продорима, ширином и слојевитошћу сагледавања, при чему је јасно да је одликује ретко запажена радозналост духа и висока ерудиција. Он се представља као одлично 
обавештен мислилац који на рецепцијском плану упија из бројних извора, при чему своја интересовања касније презентује тако да материја добија израз новог промишљања и одуховљења. Отуда се епистемолошки императив за Павловића не састоји у афирмацији властите ерудиције, већ у креативном и плодном настављању и надопуњавању идеја на које се ослања. Тај принцип јасно је видљив у интертекстуалној природи његове поезије. Но, то је свакако видљиво и у његовим есејима који се, у зависности од проблематике, ослањају на разноврсне човекове спознајне просторе, од оних интелектуалних, научних и филозофских аспеката који обележавају развој цивилизацијске мисаоности, до најширег оквира човековог духовног искуства света, који у себе укључује контексте усменог и уметничког стваралаштва, као и познавање различитих митолошких система. Отуда ће његово промишљање мита, и ово у Дневнику пене, али и у књигама које ће тек уследити (Поетика жртвеног овреда, Говор o Ничем, Храм и преображење), увек подразумевати богату рецепцијску упућеност, односно искуство антрополошких истраживања и археолошких налазишта. Та искуства фино су и функционално проткана у његовим есејистичким текстовима, осећа се специфична поетско-мисаона надградња у њиховој артикулацији, па и у нијансирању смисла. У том контексту чини нам се занимљив следећи фрагмент: „Мит је претпоставка да је пре сваке историје постојала још једна историја, пре сваке цивилизације, једна друга, виша цивилизација (Павловић, 1972: 41). Ова теза, узбудљива и заводљива, у себи носи одјек познавање индијске митологије, која ће још неколико пута оставити трага на Павловићевом стваралаштву. У књизи Говор о Ничем аутор ће ce, разматрајући феномен апокалипсе са митско-антрополошког аспекта, позвати на књигу Вишну пурана из индијске митологије која у структури свог митског мишљења подразумева идеју генезе из апокалипсе, али без свести у новом човеку о оном што је претходило (Павловић, 1987: 89), што је, рецимо, мотив који се препознаје у Павловићевим Карикама (Павловић, 1977), у песми „Бивша вера“. Ова митска претпоставка о историји пре историје, о циклусу пре циклуса, али и о потпуном одсуству сећања на претходеће, није само есејистички привлачна тема, и Павловић ће се њоме заправо први пут бавити у својој поезији. Она ће добијати своје уметничко моделовање и варирање у више наврата, и то по правилу тамо где је тематизована „смрт епохе“, што је наглашеније присутно у Млеку искони (Павловић, 1962), посебно у песми „Обичан човек о стварању света“. 


\section{Записи о еротском}

Посебно поглавље представљају „Записи о еротском“. Аутор наставља са фрагментарним поетско-рефлексивним узлетима и максимама, овога пута над феноменом еротског и њему блиским темама, попут жене, љубоморе, идеализације. Ови микро-увиди тешко се могу разматрати у својој укупности јер им фрагментарност одриче композициону целовитост, али треба навести да они луциднији, у нешто измењеном сензибилитету дискурса, свакако, иду за линијом Дучићевог Блага иара Радована или Андрићевих Знакова поред nута. Тако ће аутор еротско промишљати најчешће из психолошкосоциолошког угла, наглашавајући различите његове аспекте час кроз тон мудрости ${ }^{7}$,Еротско нас до краја чини свесним наше телесне природе и њене распадљивости, отуд еротско бива чак и поучно, што се у средњем веку боље знало него данас. Оно је сласт и разорење, и узлет и судар“, час кроз тачну, али неочекивану отвореност: „Неко нам се допада због физичке магије, чешће: због врсте односа коју са том особом можемо замислити“, час кроз изненађујуће дубок антрополошки продор: „(Еротизам је) повремена носталгија за заједницом јазбине“, час кроз извесну наивност: „Афродита је настала од пене, пена је хладна. Најбоље жене су мало хладне“.

Но, у одељцима „Еротско идеализовање“, „Донжуанизам“, „Порнографија“, рецимо, Павловић укључује књижевно-историјску контекстуализацију, те своју тему разматра и на примерима трубадура, Хелдерлина, Бокача, библијског Лота и, нарочито, Дантеа, који ће управо својим поетским решењима подстаћи Павловића да напише посебне есејистичке странице у оквиру књиге Читағе замишљеног (Павловић, 1990). У „Донжуанизму“, пак, миту донжуанизма он наглашено прилази кроз антислику, односно одрицањем од увреженог мишљења о овој теми. Тако, очуђујући преокрет који Павловић прави у приступу овом проблему садржан је у оспоравању тезе по којој се у основи донжуанизма налази „анксиозност, неспокојство људи који траже олакшање у сексуалној игри или такозваном

\footnotetext{
${ }^{7}$ У овом тону могу се читати и сегменти које пише у књизи Храм и преображење, где аутор, промишљајући еротски импулс у контексту сакралног, упутно указује на пропустљивост границе између светог и профаног: „Еротски нагон даје енергију посвећења, отуд толике забране које се односе на еротски живот човеков, не да се та његова страна омаловажи, него да се искористи као један од највећих енергетских извора тела и душе“ (Павловић, 1989: 90).
} 
завођењу“ (Павловић, 1972: 62). Он у духу антислике, или деконструкционистичког промишљања, обрће тумачење и истиче, у најважнијем свом делу, да такве еротске ситуације стварају заправо „најинтензивније осећање живота, ван којег му све друго изгледа као сивило и смрт“. Последица такве љубавне „посвећености“ јесте извесна анксиозност, неуравнотеженост, а не обрнуто: „Неуравнотежен, фрустриран повремено, неспокојан, човек мора постати зато што је донжуан, а не обрнуто“ (Павловић, 1972: 62), где под ,донжуанизмом“ не подразумева само љубавну, већ и сваку другу врсту (професионалне) преданости.

Павловић he касније, у „Прологу“ ове књиге, консеквентно метафизички поентирати, посматрајући еротизам као чежњу за проширењем и продужењем живота. Феномен еротског и Дон Жуанова „прегнућа“ спајају се заправо у снажној чежњи да се јунак одупре смрти, јер се у сексу, у „чину присуствовања у другом бићу“, слути превазилажење смртности (Павловић, 1972: 131), изводећи притом ефектну аналогију између Дон Жуана и Фауста:

Дон Жуан је неко ко у снажној чежњи да се одупре смрти хоће да буде присутан у свим женама као што је Фауст човек који жели да његова свест и његова личност буду присутне у свим идејама. Фауст је духовни Дон Жуан (Павловић, 1972: 131-132). ${ }^{8}$

Павловић у својим фрагментарним рефлексијама пледира за једну другачију представу човека у љубави и еросу. Постојећа представа ових феномена, устаљеност њиховог дефинисања и поимања за Павловића нити је довољна, нити је исправна, па позива на њихово прекорачивање и преобличавање, односно на препознавање и проналажење њихових нових, а правих суштина. Његова онеобичена филозофија интригантно иде у правцу разматрања човекових еротских ситуација, и то не кроз уобичајену призму морално-социолошке норме сувременог (пуританског) друштва, већ кроз један спој митског и антрополошко-психолошког разматрања:

Љубав је први корак ка педерастији, односно хомосексуалности. Љубоморан човек замишља вољену жену како спава са другим мушкарцем, изједначује се

8 По Мелетинском, ритуално-митолошка књижевна критика Нортропа Фраја проширила је појам мита на проучавање ,' 'вечитих ликова', попут Дон Жуана, Фауста, Дон Кихота, Хамлета, Робинсона“, који су „послужили као 'парадигме’ за наредну књижевност, тиме што покушаји уметничког тумачења истих уметничких типова настају стално изнова“ (Мелетински, 1976: 107). 
с њом, и тако неприметно склизне у идеју да тај мушкарац уствари њега обљубљује, што му буди одвратност, револт према жени, слабост (Павловић, 1972: 65).

Притом, у контексту схватања еротизма као „раскрснице фиктивног продужавања себе у потомству“, наведени цитат добија још више на јачању неочекиваног поентирања у промишљању љубоморе. Но, интересантно је да ово ново и другачије сагледавање сексуалног промискуитета и оргије, рецимо, и уопште еротског, које је овде интензификовано, у самој његовој поезији неће тако често добијати уметничку транспозицију. Када се јавља уочљивије онда је то или у наглашавању еротске основе природе, као у Октавама (Павловић, 1957), или у контексту оргијастичког заноса и жртвеног ритуала у циклусима Orgia sacra и Orgia profana (Павловић, 1996). У том погледу, за Павловића песника танатос је неприкосновен, и (ауто)поетичку тезу о смрти као великом искушењу песничке имагинације његова властита поезија у потпуности оправдава. Пре неголи телесне и еротске, рекло би се он је песник метафизичке оријентације. Но, ова два става и нису супротстављена. За Павловића и духовне манифестације и опредељења могу имати ознаку еротског, или прецизније, промискуитетног. Видели смо то на примеру „Пролога“ и схватању Фауста. Међутим, он врло заводљиво износи и тезу да се у „модерном интересу за историју“ препознаје:

израз промискуитетне жеље да се помешамо са људима који су измакли нашој животној церемонији, јер их више нема. Шта сте осећали када сте ходили по мозаицима римских купатила, или се завлачили у оријенталне амаме? (...) И није ли историја коју ми пишемо о другима обезбеђење да ће и нас једног дана, када нас више не буде било, задржати у друштву људи (Павловић, 1972: 132)?

Еротско сада постаје одраз духовне жеље и страсти за реактуализацијом историје и мита, и у том интуитивном и имагинативном процесу оживљавања повести он луцидно препознаје један сублимирани печат промискуитетног. У том смислу, излишно је напомињати да је безмало целокупан Павловићев стваралачки опус дубоко условљен и одређен овим духовно-еротизованим принципом. Исте године када су ови редови „Пролога“ писани, 1962. године, излази и његова песничка књига Млеко искони, чиме ови наводи постају још један пример у низу његове јасне аутопоетичке свести. Другим речима, не силази ли тада Павловић кроз своју поезију до историје и мита, до Одисеја, Ореста и Пиндара, до Агамемноновог гнева, до нарицања жене Хекторове (а касније и до бројних других цивилизацијских тачака), 
управо не би ли му поетска „промискуитетност“ обезбедила задржавање у друштву људи, односно трајање?

Унутар Павловићевог есејистичког опуса Дневник пене унеколико се разликује од других остварења. Но, иако проблемски и дискурсно разноврсна, и фрагментарније неголи иједна друга његова књига, али тим и „поетскија“ (,фрагметни су свадбени знаци идеје“, рећи ће Маларме), па и жанровски слојевитија, она се данас ипак поима као део конзистентног развијања Павловићевог промишљања литературе. У моменту објављивања вероватно је деловала необично, одударајуће, па и провокативно, но данас ову књигу и њену тематизацију поезије, имагинације и митско-антрополошких основа литературе, засигурно прихватамо као још један кохерентан сигнал Павловићевог певања и мишљења.

Ђорђе М. Деспић

ON PROBLEM AND DISCOURSE ASPECTS OF MIODRAG PAVLOVIĆ'S FOAM DIARY

\section{Summary}

Within Pavlović's essayistic opus, Foam Diary differs somewhat from other works. Although problematically and discursively diverse, genre-layered and more fragmentary than any of his other books, it is still understood today as part of the consistent development of Pavlović's reflection on literature. At the time of publication, it probably seemed unusual, outlandish, and even provocative, but today we certainly accept this book and its thematization of poetry, imagination, erotic and mythical-anthropological foundations of literature as another signal of coherence in the context of Pavlović's poetry and thinking.

Keywords: essay, poetry, discourse, imagination, myth, erotic, fragmentary

\section{ПРИМАРНА ЛИТЕРАТУРА}

Павловић, М. (1972). Дневник пене. Београд: Слово љубве.

\section{СЕКУНДАРНА ЛИТЕРАТУРА}

Деспић, Ђ. (2008). Порекло песме. Зрењанин: Агора.

Кајзер, В. (1973). Језичко уметничко дело (превод: Зоран Константиновић). Београд: СКЗ. 
Мелетински, Е. М. (1976). Поетика мита (превод: Јован Јанићијевић). Београд: Нолит.

Павловић, М. (1987). Говор о Ничем. Ниш: Градина.

Павловић, М. (1996). Изабране и нове песме. Београд: Просвета.

Павловић, М. (1977). Карике. Крагујевац: Светлост.

Павловић, М. (1962). Млеко искони. Београд: Просвета.

Павловић, М. (1957). Октаве. Београд: Нолит.

Павловић, М. (1989). Храм и преображеюе. Sfairos, Београд 1989.

Фрај, Н. (1979). Анатомија критике (превод: Гига Грачан). Загреб: Напријед. 